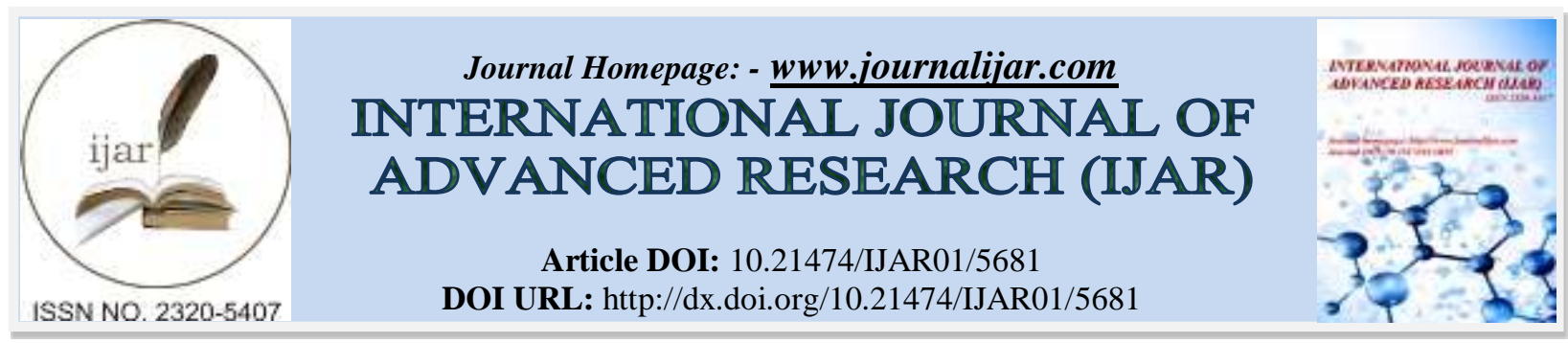

RESEARCH ARTICLE

\title{
COMMEMORATION OF THE GENOCIDE PERPETRATED AGAINST TUTSI IN RWANDA AT LOCAL LEVEL: POLICY ANALYSIS-PRACTICES-CHALLENGES-COMPETENCES AND PERSPECTIVES.
}

BIMENYIMANA Valens.

University of Kibungo (UNIK).

\section{Manuscript Info}

Manuscript History

Received: 21 August 2017

Final Accepted: 23 September 2017

Published: October 2017

Key words:-

Memory, Genocide perpetrated against Tutsi, Public Policy, Commemoration, and Decentralization.

\begin{abstract}
One of the good strategies to fight against human tragedies is to build strong memory around what happened with an aim of keeping historical facts on one side and educating current and future generations on the other hand. The genocide perpetrated against Tutsi in Rwanda in 1994 aligns with that framework and its commemoration has been at the center of efforts and political programs by the government of Rwanda. In fact, over the last twenty three years, the genocide has been publicly and officially commemorated inside and outside the country, with a neat improvement in its planning, execution and evaluation. Since 2013, commemorative activities are decentralized from national level to grass root level, in order to allow great and efficient involvement of different categories of Rwanda and hence, contribute to the reconstruction of shared history and memory around that genocide. This paper intended to explain how that decentralization is being implemented at local level, with an emphasis put specifically on policy analysis, practices, challenges, competences and perspectives. Interviews with key people as well as a thorough documentary analysis helped to gather and analyze data on what is really done and how to improve commemorative activities in future.
\end{abstract}

Copyright, IJAR, 2017, All rights reserved.

\section{Introduction}

Today, there is no doubt about one fact: the genocide occurred in Rwanda in 1994. It targeted the Tutsi minority and moderate Hutu and it claimed more than one million (MINALOC, 2004). According to several authors, the genocide was the result of a long and meticulous plan by the regimes that ruled Rwanda since many decades past. The brutality and celerity during its commission show how it was total (Kimonyo, 2008), given the extent to which all categories of people (officials, intellectuals, security organs, simple peasants...) deeply got involved. After that tragedy, a huge task of the new leadership consisted in reconstructing damaged infrastructures on one side, and healing wounds all categories of Rwanda had experienced on the other side. Without enumerating all efforts made over the last twenty three years to rehabilitate the country, this work intends to explore the role of commemoration of the genocide against Tutsi in building the memory of genocide. In particular, a focus is put on seeing how the commemoration policy started, how it evolved and how it can be decentralized in order to serve the purpose of genocide memory and well help all Rwandans as well as the international community. 
As far as this work is concerned, different types of memories are defined and the relationships/conflicts between them explained. A discussion is made on whether a nation and its people should remember and commemorate their tragic past or forget in a bid of moving forward. The debate here seems endless. Hence, here comes in the role of national/official memory versus individual and group memory. Lastly, a particular emphasis is put the genocide memory as well as the place and function of the commemoration of the genocide perpetrated against Tutsi in Rwanda in 1994 (as one of many elements making the genocide memory). Our theoretical development and analysis of collected data focus on how the commemoration, as it is done today, would be decentralized in order to well play its role in genocide memory. A look is put on policy analysis-practices-challenges-competences and perspectives as it is the current practice with the National Commission for the Fight against the Genocide (CNLG).

\section{Research questions}

The concept of memory seems complex especially when it comes to the commemoration of the genocide perpetrated against Tutsi in Rwanda as one of major tools of the genocide memory under construction since 1994. The theme of commemoration attracted our attention in this work because we want to analyze it in diachronic way through elements from field research and documentary search. Therefore, the present work aims at responding to the following research questions:

a. Does the way genocide against Tutsi is currently commemorated help all Rwandans to build and strengthen its memory as well as the national collective memory?

b. What are challenges encountered and how to overcome them?

\section{Hypotheses}

This work started from the statement that the way commemoration is currently conducted does contribute or not to the construction and reinforcement of national genocide memory. What is being done in Rwanda during the commemoration of the genocide has been analyzed in a bid of sorting out what contribute to national memory of the genocide. This main hypothesis can have the underlying sub-hypotheses such as the debate whether local history may imply local memory policy. In this regard, some people wonder if the local history should inspire local commemoration through speeches and practices, for the fact that in many cases genocide matters happened in one specific area in different way than in another one. So far, the main impression seems that only national genocide memory has been prevailing and guiding the whole commemoration process. Meanwhile, as time goes on and people (especially genocide survivors) get liberated from sadness, anxiety and trauma, they express the feeling and necessity of being closer to their local stories; from that, living in intimacy with their deceased beloved relatives. This leaves the feeling that local commemoration would be more helpful, at least at individual level, as it is strongly linked to individual memory.

\section{Methodology: documentary and interview (Qualitative approach)}

In this research, both documentary and interviews were used. According to Bryman (2001), the documentary analysis covers a variety of sources, including official statistics, photos, audio-visual texts and data. He asserts that the documentary analysis can be a useful tool when engaged in socio-historical analysis. As we will show it in further development, commemoration of the genocide perpetrated against Tutsi is one of many tools resorted to in order to build and keep the genocide memory. We can mention here memorial sites, official annual themes issued by the cabinet, speeches, decent burial of victims, etc. The main document we used concerns the public policy of memory in Rwanda (CNLG, 2008), books, reports, online sources all related to the genocide perpetrated against Tutsi in 1994.

\section{Literature review}

This section focuses on three major concepts, i.e. definitions and the role of memory, the public policy analysis as well as the commemoration of the genocide perpetrated against Tutsi. Social representations have been briefly evoked in the logic of raising the controversy around the commemoration of the genocide by all categories of Rwandans. Memory, commemoration, identity, reconciliation are all themes and concepts which frame within efforts of reconstructing the country that was torn apart by the tragedy of genocide and its consequences. Today, Rwandans and the international community rejoice at the development made to resuscitate Rwanda from the ruins after the 1994 genocide. In short, the post-conflict reconstruction of Rwandan society seems successful at many levels of social life. 


\subsection{Definition of key concepts 4.1.1. Memory}

The concept of memory is complex to work out given its plurality. Memory is defined as a set of practices and experiences. In consideration of its types, there is individual memory, collective memory, official memory and national memory. Memory is plural. ${ }^{1}$ Collective memory is "a relatively stable combination of creeds, values, knowhow, representations of events shared among the members of human groups which are inscribed in lasting manner, not only in the spirit but also in a common space realized in texts, instruments, monuments, mnemotechnic practices, etc." This statement means that collective memory is about events that all people accept and share or make their own about the past. For instance when people remember how they used to bury their dead, the rituals and ceremonies they shared, words used, the dressing, eating, cooking ways, etc. This makes collective memory because everybody owns them/it.

In another development, Nsanzubuhoro Eric defines individual memory as "That one which is transmitted across the actors and witnesses of the event. It is a particular memory of families, groups or local and cultural memories" ${ }^{2}$. In other words, this memory refers to an event that is limited to a particular group or family without involving all people.

From individual memory we move to official and national memory. Maurice Hallbwacks defines official memory as: "a collection of events which are supposed to be the most remarkable people's memory which have contributed to change nations or institutions. Read from books or experiences, the past events are chosen, approached according to the needs or rules that were not binding people who have owned them for a long time" 3 .

An example of official memory is the commemoration of the genocide perpetrated against Tutsi in 1994 which is now compulsory to everyone (Rwandans and foreigners). In Eric's terms, official memory is also understood as "an expression of a political power which is seen in commemorations often influenced by the present and is suspected of being the mobilization tool" " "The national memory is the patriotic and heroic expression of an official memory which tries to put accent on its singularity and a dominating collective memory which has risen to the level of a myth"5. An example of this type of memory is the Heroes' Day in Rwanda ${ }^{6}$.

\subsubsection{Memory and history}

Talking about memory, Valérie Rosoux states that "memory is the mental patrimony, a set of memories which nourishes representations, insure individual cohesion within a group or a society and which can inspire their present actions". In other words, memory is the process of the reconstruction of the past, of restitution of memories from references points from present social environment (Maurice Hallbwacks). It is the past made present (Paul Ricoeur). In brief, memory is made of past memories and representations which are rekindled in social contemporary space. Let's conclude this reflection about memory with Pierre Nora who states that: «La mémoire est le souvenir d'une expérience vécue, portée par des groupes vivants, ouverts á toute transformation, inconsciente de ses déformations successives, vulnérable á toutes les manipulations, susceptible de longues latences et de brusques réveils ». [Memory is the remembrance of the past experience that is carried out by living groups, open to any transformation, unconscious to successive distortions, vulnerable to all manipulations, likely to undergo long-lasting latency and abrupt reawakening].

One can't talk about memory without stressing its relationship with history, for the simple reason that the two terms confuse the public in many cases. Therefore, in the views of Professor Mukuru from the University of Burundi:

\footnotetext{
"History and memory, the past and the present are two couples with similarities indeed, but also their own specificity History and memory have been taken as synonyms for long time, even confused, for the more that they are both ways to inform us about the past. The past in what is no longer there, what does no longer exist, what can never come again. In this case, it is opposed to the present because the present has existence while the past has none. You can change or modify the present. Meanwhile, if you observe closely the organization of the societies, you can say that the

${ }^{1}$ Paul Rutayisire, Memoire et/ou oubli comme rançon à la paix civile, Catholic Relief Service Rwanda 2003

${ }^{2}$ Nsanzubuhoro Eric, La Mémoire du Génocide et la Problématique de sa Gestion Politique au Rwanda, p.25

${ }^{3}$ Hallbwacks Maurice, Collective memory, PUF,Paris, 1968, p. 60-67

${ }^{4}$ Nsanzubuhoro Eric, op.cit. p. 25

${ }^{5}$ Idem

${ }^{6}$ Idem
} 
past exists through memories, which the past and the present clash, meet and mutually condition each other.....We only talk about the past in present. Le past only exists through memories. It never dies" ${ }^{\prime 7}$.

\subsubsection{Memory of genocide perpetrated against Tutsi}

Before we explain the memory of genocide and its place in public policies, it is worth starting by defining it through its necessity to the Rwandan and international community. In the views of Nkusi L. (2010), memory is necessary especially when it comes to the genocide, an imperceptible crime, a crime you can never erase; mainly because the planners and implementers of the genocide, while committing it, deny it at the same time by erasing all proofs. In the front of the genocide reality, backfires appear:

a. Those who deny the existence of the genocide against Tutsi (without any intention)

b. Those who trivialize the genocide by altering its true nature( for instance talking of civil war)

c. Those who raise the logic of "double genocide"( one dirt of Hutu against Tutsi and one clean of Tutsi against Hutu)

d. Those who justify the genocide (Tutsi deserved it!)

e. Those who advance the auto-genocide of Tutsi against themselves: Why did RPF attack the country on $1^{\text {st }}$ October 1990? While, traditionally, such attacks were always followed by pogroms?

f. Those who talk of genocide as business deal for politicians, " you give much care to skeletons exposed in different memorial sites( because it earns lot of money) rather than to survivors who live miserably" ( L. Munyakazi)

g. Those who criticize the emotional language around the exhumation of dead (S. Desouter)

h. Those who confuse voluntarily the concepts of civil war, war crimes, cholera and genocide

Late Professor Misago (2008) justified the role of memory of genocide as consisting in:

Assuming the distressing episode of the Rwandan history in order to assure a good cohabitation between present groups by reducing antagonism and a possible future to next generations;

a. Rehabilitating in their humanity, victims and survivors of the genocide, restore human feelings to planners, instigators and executors of the genocide and to keep aware the international community;

b. Serving as the driving force behind the fight against denial;

c. Prevention of genocide ideology;

d. Serving as education tool for peace, unity and reconciliation, the transmission of Rwandese cultural values on basis of national identity.

To achieve this, he developed and explained what he called memory tools similar to what is being used today during the commemoration of the genocide perpetrated against Tutsi. To sum up this discussion on memory and history, let's come back to Maurice Halbwachs (Op.cit.) who confirms that memory is heterogeneous and specific, collective and individual in one moment. On the other hand, history belongs to everyone and no one because it lays claim to be a universal authority".

\subsubsection{Memory policy as part of public policies}

The memory policy falls in framework of what is commonly labeled as public policies. Therefore, before we elaborate more about the policy of the genocide against Tutsi as well as its commemoration, it is worth having a look at public policy, how it works and how it is evaluated. In doing so, we will lay the basis of analysis to what is being done in Rwanda since 1994.

The concept of public policy is generally defined as action (or inaction) that is undertaken by the government vis-àvis a particular question. Other specialists define it as "actions, statutory measures, legislation and funding priorities about a particular topic which was promulgated by a government entity or its representatives. Public policies are mostly incorporated into constitutions, legislations and judiciary decisions.

According to W. Michael, the elaboration of public policies is a complex and multifaceted process that involves many people and groups with diverging interests and the collaboration to influence decision-makers to act in certain way. These people and groups utilize several tactics and tools to advance objectives, by defending positions in public and by sensitizing supporters and opponents and by mobilizing the allies on a particular question.

Objectives of public policies:

a. Assuring the education of citizens

\footnotetext{
${ }^{7}$ Notes de cours du Professeur Mathias Mukuru, Université du Burundi, Kigali, 2014
} 
b. Assuring security and keeping the rule of law

c. Maximizing the well-fare and income per inhabitant

d. Allowing job creation and avoid poverty

e. Maintaining good health to the population (prevention against AIDS ...), medical care and vaccination campaigns...)

f. Allowing free movement of people and goods (building transport networks)

For some people, public policies should play the role of redistribution when chances are not equally assured at the beginning.

\section{Means used by public policies}

a. Creation and increase of some taxes

b. Allocating budgets to organisms, agencies, services I order to enable them achieve their objectives

c. Advertising the public policy through official sphere in order to incite citizens to participate

\section{Evaluation of public policies}

Evaluating the public policy comes to measure its efficiency with performance indicators in order appreciate the pertinence. Evaluations must be conducted in order to verify if public policies achieve their objectives efficiently ${ }^{8}$.

\subsubsection{Memory Policy}

Memory is a political tool by which events are memorized and written or rejected. The terminology deals with the role of politics in the elaboration of collective memory and how memories can differ greatly from the objective reality of events as they occurred. The influence of politics on memory is perceived in the way the history has been made and transmitted. Memories are influenced by political and cultural forces. Government policies and social rules as well as popular culture and social norms have impact of how events are memorized.

In political matters, memory gathers all tools likely to ignite the interpretation of historic and political events in order to achieve specific objectives. That process of memory can be done into three phases: the establishment of facts, giving them a meaning or interpretation of established facts, and putting in service the past into present in order to achieve current objectives. The content of memory may vary according to each one's experience in front of the object to commemorate and objectives to achieve.

The memory to be undertaken in our country is an exemplary one which takes the past in order to correct the present and insure a bright future. This memory serves to remind successive generations what should not be repeated again. It promotes the repentance, forgiveness, reconciliation and harmony ${ }^{9}$.

In the views of Paul RICOEUR, keeping memory consists in immortalizing all victims in collective memory of the nation. It is in this framework that related public policy has been put in place in order to guide all actions of genocide memory, for the more that the national unity which is the expression of active conscience to belonging to the same nation and sharing the same fate constitutes a precondition to any initiative of sustainable national development. The end goal of memory policy is to remove that challenge. It is also a means to resist future genocides, to teach future generations to build a nation without ethnic labels once for all. The importance of a national memory policy lies in the future of the national memory which, so far, is supposed to reflect the memory of genocide perpetrated against Tutsi in Rwanda in 1994. Thus, the government strived to determine what should be remembered and how this should be done, on the basis that the majority of these elements marked the recent history of Rwanda ${ }^{10}$.

\subsection{Conservation of the memory of genocide perpetrated against Tutsi}

We have analyzed different aspects of memory in general as well as its specificity in the Rwandan case. Memory is a subset of public policies and it is not synonymous of history though they share many similarities. Hence, memory is part of history. Now, we focus on efforts of constructing and keeping the memory of the genocide perpetrated

\footnotetext{
${ }^{8}$ W. Michael Schuster II "for the greater good: the use of public policy considerations "Houston Law review, Vol. 46,2009

${ }^{9}$ Thorsten Keiser, Confronting memories-memory, politics and law Europeanization as a challenge to legal history, 2009

${ }^{10}$ Institute of Research and Dialogue for Peace, Rwanda Tutsi Genocide: Causes, Implementation and Memory, 2006
} 
against Tutsi by highlighting what has been done so far. A focus is put on commemoration in general and how it would be decentralized in order to achieve the objective of genocide memory. A section is developed on the controversy to that concept and how it is handled by some scholars/authors.

In order to make and maintain national collective memory, a certain organization is needed. Therefore, the memory of the genocide perpetrated against Tutsi is an absolute imperative for Rwanda which strives to curb the culture of impunity and rebuild a torn- apart nation. In addition, the genocide memory constitutes a preventive mechanism to future horrors and genocides in the World. The most seen specificity of the memory of the genocide perpetrated against Tutsi lies in temptation to have a "collective mourning" through commemorations that have been organized since 1995. At the beginning and at local level, associations of genocide survivors got involved mostly, with a hesitating attitude of the remaining public due to different presupposed reasons: some felt less concerned with the event, others felt either guilty in one way another in what happened in 1994 and thus felt frustrated. As far as the construction and keeping of the genocide memory is concerned in Rwanda, we have noticed a series of activities and initiatives which increased over time since the last twenty years to the point that now commemoration gathers all categories of the population as well as members of international community. The section below highlights some of these activities.

\subsubsection{Memorial sites}

There is no doubt that memorial sites across the country constitute the real image and reality of the genocide perpetrated against Tutsi. Every year, since 1995, the mourning week is marked by several ceremonies of burying genocide victims in dignity. At the beginning, this seemed like a business of individuals, families and associations of survivors in the same region, with the support of local authorities. The decent burial depended on available means and the commitment of survivors and the public around. Though some abnormalities and malfunctioning have been noticed, a great deal and efforts allowed burying hundred thousands of dead people from mass graves, open hills and public buildings. Obviously as time goes on, a lot of memorial sites get old or deteriorated and need rehabilitation. Recently, a law on the categorization and decentralization of memorial sites has been proposed by the CNLG ${ }^{11}$, mainly for regulating disputes and misunderstandings between genocide survivors and authorities on where and why to establish memorial sites. In next days, we may expect to have international, national and local memorial sites when this specific law will be passed. Let's remind here that all works related to the construction, supervision and maintenance of official memorial sites fall under the direct responsibility of CNLG.

We do need to remind the role of memorial sites: on one side, it reminds the humanity the process of the tragedy of genocide against Tutsi in 1994 in Rwanda took away on one side, on the other hand, it heals the genocide survivors who, by visiting them and commemorating, feel close to their beloved relatives and find in them strength to move forward despite sadness, fear and loneliness. In addition, these memorial sites remind the public the torture the victims endured during the genocide and hence, and teach them to respect life and fight for peace. We can also rejoice at the fact that the public has gradually changed the mindset about the controversial debate of exposing bodies in memorial sites- this is against traditional and religious beliefs about rituals and burying people- A big issue resides in the assessing if really memorial sites and commemorative events help survivors and the public in general in building individual, local and national memories. The impression as we will show it in the data from our interviews is that commemoration bears more a political and ceremonial coloration rather than serving the mourning, healing and resilience purpose. Lastly, we would believe that all memorial sites play the preventive role against future tragedies ${ }^{12}$.

\subsubsection{Commemoration}

For all Rwandans, commemoration should be the appropriate moment to meditate about that painful passage of their history by focusing on the reconstruction of social fabric. Group commemorations according to the sites and places got momentum with the government of commemorating the genocide every year since 1995. After all, Rwandans found their own ways to commemorate the genocide in complex social political context. As we mentioned it earlier, the participation in commemorative activities got increased crescendo since 2004 when the government decided to commemorate the genocide from 7-13 April every year. Of course, many campaigns of sensitization yielded fruits in

\footnotetext{
${ }^{11}$ The National Commission for the Fight against the Genocide (CNLG) is now the government body tasked with regulating and governing whatever is related to genocide matters: burial activities, commemoration, teaching programs, construction, memory and conservation among others.

${ }^{12}$ More on this topic has been developed by Rudagocora (2004) in his "Mémoire des sites et sites de mémoire au Rwanda après 1994"
} 
that matter. The modus operandi of commemoration looks almost the same: speeches emphasizing the "Never again"; reliefs and condolence messages to survivors, attempts to give identity and dignity to victims where names are sometimes written on walls of burying sites; efforts to organize commemoration near/around memorial sites which, in many cases represent the famous killing places.

Up to now, official commemoration of the genocide perpetrated against Tutsi is organized at national level, and the places hosting ceremonies change every year ${ }^{13}$. Along we have had national and international conferences where genocide matters have been discussed in scientific and scholarly fora ${ }^{14}$. Since 2010 , commemorative activities have been decentralized up to village level and they involve all people. This decentralization of commemoration needs an assessment in order to learn their receptivity, the capacity and competence of local people and authorities to talk of genocide issues as due, the influence of ordinary politics, support to disabled survivors.

Along the formal and official commemoration, people in their gathering and relationships, organize individual or group commemoration throughout the 100 days ${ }^{15}$ of commemoration. In the same logic, people thrown in lakes and rivers are remembered; children and teachers are remembered.... Let's mention here that even memorial sites have been erected in neighboring countries (Uganda and Tanzania for instance) to honor the memory of victims. Whatever is done, it is realized that many survivors and the general public feel at ease when they commemorate the genocide where they survived or where their relatives perished. Here comes in the role of a well-planned commemoration in the healing process.

\subsubsection{Themes and speeches}

At every commemoration, a theme is proposed by the Cabinet Meeting in order to guide preparations and speeches around the commemoration of the genocide. Most of time speakers are made up of survivors who give their testimonies, the IBUKA ${ }^{16}$ leaders at different levels and officials depending of the extent and place of commemoration. For instance in district, the Mayor may be the guest of honor. At national level, the President of Republic addresses the public on basis of the theme chosen. As we mentioned it in previous section, since 2010 the commemoration has been decentralized at grassroots level. Now the standardized model is that the CNLG with the support of concerned public institutions prepares written talks on chosen topics (ranging from genocide ideology and history, social-economic well-fare of survivors, security issues.....) and send them to be used by all institutional levels throughout the whole morning week. This implies that the commemoration is organized and conducted in the same way throughout the country. The issue of local memories and history is left out, giving the commemoration the political image like any other normal events. Another move we noticed in the last two commemorations is that people (including survivors) tend to highlight good achievements and hide real and complex problems survivors face in their daily life (housing, medical care, trauma, insecurity...). The tendency is to highlight good achievements by political institutions.

\subsubsection{Walk To Remember}

The «Walk to Remember » is organized by the youth every April $7^{\text {th }}$ in the afternoon, prior to the night vigil. This initiative started in 2008 by the Never again Rwanda Chapter before it got adherence and full support of officials at all levels. In the last two commemorations, the walk to remember was organized across the country, contrary to the initial ones which were organized only in Kigali City and most of time the President of Republic along with high dignitaries present to commemoration participate.

\subsubsection{Guided visits to memorial sites}

The government of Rwanda through its channels encourage people (both nationals and foreigners) to visit the country and get to know what happened during the genocide perpetrated against Tutsi. Teaching sessions are organized targeting mainly the youth under 20 , in the spirit of telling them the truth, preventing future tragedies and fighting against denial tendencies and movements. In this regard, people in cooperatives, teachers and their students at different levels (nursery, primary, secondary, higher learning...) organize trips and study tours to Gisozi Genocide Memorial or to the nearest sites where they get explained about the genocides in general and the genocide perpetrated against Tutsi in Rwanda in 1994 in particular.

\footnotetext{
${ }^{13}$ The list of 20 themes proposed since 1995 is available for consultation at CNLG, an the latter have been subject to many studies

${ }^{14}$ See conference proceedings at the CNLG Documentation Center since 2009.

${ }^{15}$ This is the official period set by IBUKA to commemorate the genocide for 100 days, i.e. up to July every year

${ }^{16}$ IBUKA is an umbrella of genocide survivors' associations.
} 


\subsubsection{Moral and material support to disabled genocide survivors}

As time went on, the general public realized the acute needs many vulnerable survivors (food, shelter, medical care...) expressed especially during the commemoration week, despite the government support through FARG ${ }^{17}$. Thus, people of goodwill gather different donations and distribute them to genocide orphans, widows and elderly in need. The problem here, to some part of public opinion, remains the use of these donations as advertisement by some people/institutions, which is totally against the intentional goodwill ${ }^{18}$. In any case, we can see that much has been done to improve and diversify the ways commemoration of the genocide against Tutsi has been conducted, especially the mindset change of the general public and the international community. We do believe that a thorough assessment may help decision-makers to know the journey covered and what it has yielded. Our main concern has only been to assess how the decentralization process was done, in particular the talks that are prepared from the top management to be channeled and delivered at grassroots level (village) during the mourning week.

\section{Research findings and their interpretation}

We have expressed in the introduction that we wanted to analyze the conduct of commemoration of the genocide perpetrated against Tutsi in Rwanda in 1994, as one element of building its memory. In fact, a good step has been made with the decentralization of commemoration since 2008, as well as the establishment of the CNLG to guide and regulate all activities in the matter. And yet, we do recognize that there are still some challenges to overcome in order to help all categories of Rwandans and the international community to well and fully commemorate the genocide perpetrated against Tutsi. This section wants to discuss what came out the interview we conducted with some people/officials who get involved directly in the commemoration. The experience of the last three years has been inspiring as far as the decentralization of the commemoration is concerned. And yet, the speedy evolution of social political situation in Rwanda has a great impact on the commemoration.

\subsection{Views about decentralization of commemoration}

In general, all respondents ( 30 in total, comprising officials at CNLG level (5), leaders and staff at district level (5), leaders and staff at sector and cell level(20) appreciate the approach of decentralizing commemoration (speeches and activities). They find it very relevant because it allows many people to participate, especially after the closure of the Gacaca courts (2012) which elucidated each one's role and liberated many suspects/convicts who pleaded guilty and were forgiven. Meanwhile, the issue of competences of people who give the prepared talks remain serious in many places, for the fact that in many cases, they chose someone just because he/she is available without the capacity of addressing the big gathering on sensitive topics of genocide matters and get to adapt them to the context. They suggested carefully choosing speakers ahead of the presentations, briefing or training if need be (in some place a kind of introduction/briefing is made with all people who are involved in talks. This may be the ground rule to everyone). In addition, respondents insist on the preventive and teaching role a well-prepared commemoration would play in the community.

\subsection{The number and schedule of talks during the mourning week/night vigil}

Some people have claimed that many talks are organized the same day and participants do not get enough time to discuss them and even ask questions for clarifications. $70 \%$ of respondents do not agree with that assertion. They believe that the time may be enough and limited depending of the speakers and the organizing team who should devote balanced time to each topic and respect time keeping. As for ending the night vigil at $22 \mathrm{~h} 00$ instead of next morning as it used to be done up to 2013, views are different and have raised anger and controversy at the beginning (three years ago). $50 \%$ of interviewed people agree on ending the night vigil at $22 \mathrm{~h} 00$ in order to allow participants having time to rest and go to work next day, while 30\% think that there should be freedom: those who want go home and others remain in place until morning. So far, the rule states to close activities at $22 \mathrm{~h} 00$, and some survivors have expressed concerns about this new approach, suspecting the decrease in importance and even the tendency to the abolition of the mourning night.

\subsection{The content of talks and the importance of testimonies}

One question asked if mixing genocide-related topics with other government programs would undermine the good results from commemoration. $80 \%$ of respondents found no problem in integrating some official programs to the talks as far as they are linked to the chosen theme and help people to move forward. They insisted on testimonies provided by survivors, the perpetrators, the rescuers and by bystanders because they help knowing the truth and

\footnotetext{
${ }^{17}$ National Survivors' Fund (FARG)

${ }^{18}$ There is a way of worrying about an increasing tendency of using this support as advertising tool by some people/institutions. It really sounds bad and would undermine that good gesture.
} 
healing the whole society, hence, fostering the true reconciliation. They noticed the sound evolution that happened over the last years where other categories of Rwandans committed to give testimonies in addition to the sole survivors.

On the issue of local memories and how close stories would help survivors and people in the vicinity, $85 \%$ of respondents state that this is a very helpful approach as it helps survivors to really mourn their relatives and to remain close to their reality. Meanwhile, the issue of massive trauma among the gathering as the truth is being revealed was raised, calling the organizers and people in general to plan ahead of time and well handle those cases adequately. Building the genocide memory is a long and complex process, and the commemoration is among key tools to achieve it.

\subsection{Opinions on memorial sites and their role in building the genocide memory}

All respondents commend the presence of genocide memorial sites across the country and remind their key role in helping the survivors in their healing journey. Nevertheless, they deeply regret how many they are scattered across the country and how miserably and poorly many of those sites and built and maintained. They suggest keeping few manageable memorial sites and encourage people in the vicinity to go where they feel comfortable with. The issue of budget constraint and collective responsibility has been raised and main factor in having memorial sites in disgraceful conditions. Respondents regret the fact that memorial sites are taken care only (and most of time superficially) during the commemoration period and then left at the mercy of all evils. The CNLG and grassroots authorities were called upon to make more efforts; otherwise the genocide memory is likely to be undermined or even forgotten in future, hence, unintentionally encouraging the denial movements.

For the regions which did not experience the genocide, they advise to build memorial and establish documentation with stories from other places where people would come and get to know what really happened. The genocide is the crime against humanity and it should be prevented by the whole humankind.

\subsection{Views about genocide commemoration vis-à-vis the reconciliation process}

On the question of how the commemoration of the genocide perpetrated against Tutsi would impede the true reconciliation among Rwandans as it is argued by some people (including foreigners), all respondents disagreed on that statement, insisting on the fact that the truth telling, seeking and giving forgiveness constitute the real foundation to the long-lasting reconciliation among Rwandans. The country experienced the long history of hatred and divisions which culminated in the genocide perpetrated against Tutsi in 1994. In addition, it was the quickest and atrocious genocide because Rwandans killed their fellow Rwandans with whom they shared everything. It is obvious that reconciliation won't neither be automatic nor overlap indispensable healing process in any post-conflict society. The truth will help in preventing future tragedies on one side and shape new foundations to history remaking.

\section{Conclusion:-}

The commemoration of the genocide perpetrated against Tutsi in Rwanda in 1994 remains a vital activity to build shared and strong memory around that unimaginable tragedy. In addition, the same genocide memory will help preventing similar tragedies in future. Since 1995, much has been done to conduct and improve the commemoration of the genocide against Tutsi and make it more profitable and shared by all categories of Rwandans as well as willing members of the international community. The last step consisted in decentralization of commemoration activities since 2010 and yet this process yielded sound improvement and innovations despite some challenges as highlighted in sections above. We strongly support it and want to advocate for its improvement as time and realities keep changing with systems and people. We are aware that a totally shared genocide memory would be a bit hard to build because of disparities, misunderstanding and misinterpretation around many historical events/facts indeed, but also we recognize that that memory remains a necessity for the survival and peaceful continuity of the Rwandan society. From this, Rwandans may expect living in a truly reconciled community.

\section{References:-}

1. BRYMAN, A., (2001). Social Research Methods. Oxford: Oxford University Press.

2. FISCHER, R., et alii. (2007). Public Policy Analysis: Theory, Politics and Methods. CRC Press

3. HALLBWACKS,M.,(1968).Collectivememory. Paris: PUF From http://popups.ulg.ac.be/csp/document.php?id=568\#tocfrom2

4. Institute of Research and Dialogue for Peace (IRDP). 2006). Rwanda Tutsi Genocide: Causes, Implementation and Memory: Kigali 
5. KIMONYO, J.P., (2008), Rwanda. Un génocide populaire, Paris : Karthala

6. La mémoire collective selon Maurice Halbwachs From :http://laurent.mucchielli.free.fr/memoire.htm

7. LAVABRE, M.C., (s.d.) Usages et mésusages de la notion de mémoire [Online]

8. W. MICHAEL SCHUSTER II "for the greater good: the use of public policy considerations " Houston Law Review, Vol. 46,2009

9. MISAGO, C. «Les instruments de la mémoire », Gradhiva from: http://gradhiva.revues.org/745

10. NDUSHABANDI, E., (2013). La politique de la mémoire au Rwanda après le génocide de 1994 : étude du dispositif des «Ingando », Thèse de doctorat, Bruxelles

11. --------.-.-.-- La gestion politique de la mémoire du génocide au Rwanda: Mémoire officielle face aux représentations sociales, in Cahier $n^{\circ} 21$ [Online]

12. NKUSI L., (2010). Le Génocide perpétré contre les Tutsi : Conservation de la mémoire et de la documentation, un défi possible à relever in Actes du Colloque, CNLG: Kigali

13. NORA, P., (s.d.) Between Memory and History: Les Lieux de Memoire in Representations. The Regents of the University of California. [Online]

14. RESOUX, V., 'La gestion du passé au Rwanda : ambivalence et poids du silence' in Genèses, 2005/4 N0 61, p.28-46 From: http://www.cairn.info/revue-geneses-2005-4-page-28.htm

15. RUDACOGORA, A., (s.d.). Mémoire des sites et sites de mémoire au Rwanda après 1994. Université Nationale du Rwanda- Université Paris 13[Online].

16. RUTAYISIRE, P., (2003), Memoire et/ou oubli comme rançon à la paix civile [Online]

17. THORSTEN, K., (2009). Confronting memories-memory, politics and law Europeanization as a challenge to legal history, s.l. (Online) 